\title{
Cognitive Functioning One Month and One Year following Febrile Status
}

\section{Epilepticus.}

Erica F Weiss PhD, David Masur PhD, Shlomo Shinnar MD PhD, Dale C Hesdorffer PhD, Veronica J Hinton PhD, Melanie Bonner PhD, Julie Rinaldi PhD, Virginia Van de Water EdD, James Culbert PhD, Ruth C Shinnar RN MSN, Syndi Seinfeld DO, William Gallentine DO, Douglas R Nordli Jr MD, L. Mathew Frank MD, Leon Epstein MD, Solomon L Moshé MD, Shumei Sun PhD for the FEBSTAT study team.

Author Affiliations:

Departments of Neurology (EFW, DM, SS, RCS, SLM), Pediatrics (SS, SLM), Epidemiology and Population Health (SS) and Neuroscience (SLM), Montefiore Medical Center, Albert Einstein College of Medicine, Bronx, NY GH Sergievsky Center (DCH, VJH) and Departments of Epidemiology (DCH) and Neurology (VJH), Columbia University, New York, NY Departments of Pediatrics-Neurology (WG), and Psychiatry and Behavioral Sciences (MB), Duke University Medical Center, Durham, NC.

Departments of Neurology (JC, SSeinfeld), Psychiatry (JC), and Biostatistics (SSun), Medical College of Virginia, Virginia Commonwealth University, Richmond, VA

Department of Neurology (LE) Ann \& Robert H. Lurie Children's Hospital of Chicago, and Department of Psychiatry and Behavioral Sciences (JR) Northwestern University, Feinberg School of Medicine, Chicago, IL 
Departments of Neurology and Pediatrics (LMF, VVW), Children's Hospital of The King's Daughters and Eastern Virginia Medical School, Norfolk, VA Department of Neurology (DN), Children's Hospital of Los Angeles

Address all Correspondence to:

Erica F Weiss PhD

Division of Neuropsychology

Department of Neurology

Montefiore Medical Center

111 East $210^{\text {th }}$ St

Bronx, NY 10467

Tel: $718-944-1832$

Fax: 718-944-1940

Email: eweiss@montefiore.org 


\section{Abstract:}

Objective: To determine early developmental and cognitive outcomes of children with Febrile Status Epilepticus (FSE) one month and one year after FSE. Methods: One hundred ninety four children with FSE were evaluated on measures of cognition, receptive language, and memory as part of the FEBSTAT study and compared to 100 controls with simple febrile seizures (FS).

Results: Children with FSE did not differ dramatically on tasks compared to FS controls at one month after FSE, but demonstrated slightly weaker motor development $(p=0.035)$ and receptive language $(p=0.034)$ at one year after FSE. Performances was generally within the low average to average range. Within the FSE cohort non-white children performed weaker on many of the tasks compared to Caucasian children. At the one year visit, acute hippocampal T2 findings on MRI were associated with weaker receptive language skills $(p=0.0009)$ and human herpes virus 6 or 7 (hhv6/7) viremia was associated with better memory performances $(p=0.047)$.

Conclusion: FSE does not appear to be associated with significant cognitive impairment on early developmental measures although there is a trend for possible receptive language and motor delay one year after FSE. Further followup, which is in progress, is necessary to track long term cognitive functioning. Key Words: Cognition; Febrile Status Epilepticus; Febrile seizure; Children 


\section{INTRODUCTION:}

Febrile seizures (FS) are relatively common seizures that occur, in association with a febrile illness (temperature greater than $38.4^{\circ} \mathrm{C}$ ) without concurrent central nervous system infection or acute electrolyte imbalance, in $2-4 \%$ of children [15]. Simple FS are isolated, brief, generalized seizures and complex FS are focal, prolonged (greater than 10 or 15 minutes depending on definition) or multiple (more than one seizure during a febrile illness) [1-5]. Febrile status epilepticus (FSE) are very prolonged FS or those lasting longer than 30 minutes [2-6]. Brief and/or simple FS are thought to be benign [3-5]. FSE, however, can cause acute hippocampal injury leading to hippocampal sclerosis [6-9] and has also been causally linked to subsequent mesial temporal lobe epilepsy [6, 9-11]. There is good evidence from epidemiological studies that complex FS and FSE are not associated with impairment of global intellectual function [12-14]. However, these studies did not specifically examine memory, a cognitive function subserved by the hippocampus, which is known to be impaired in mesial temporal lobe epilepsy $[15,16]$.

The FEBSTAT study (Consequences of Prolonged Febrile Seizures in Childhood) is a prospective multicenter study following children from the time of their FSE episode with serial MRIs, EEGs and neuropsychological testing [17, 18]. It is designed to study the relationship between FSE and subsequent acute hippocampal injury, development of hippocampal sclerosis (HS) and later development of TLE. Memory and other cognitive functions are assessed and a determination is made as to whether or not children are impaired even prior to 
the development of epilepsy [18]. In this report we present the results of the cognitive testing at baseline and one year after the baseline FSE.

\section{METHODS}

\section{Participants}

Two hundred and fourteen children who met criteria for FSE and were enrolled in the FEBSTAT ( $N=199)$, and the Columbia Study of Febrile Seizures $(\mathrm{N}=15)$ studies. Characteristics of the overall samples can be found in Table 1. Comparison children with a first simple febrile seizure (SFS: N=102) were drawn from the Columbia Study.

Of those enrolled, 187 FSE and 100 SFS children completed cognitive evaluations at one month and 155 FSE and 89 SFS children completed evaluations at one year. Some children within the FEBSTAT cohort who did not complete one month cognitive evaluation completed the one year evaluation (12 children) while a percentage of the group completed one month but not one year evaluation (35 children). A small portion of the children were administered incorrect or inappropriate measures and those were exclude from the analysis. As a result, a total of 182 one month and 151 one year FSE visits were used in this analysis. As some children were only able to complete one of the measures due to age or other limitations, individuals numbers analyzed for each measure are included in each table as appropriate. We could not find any demographic or neurological differences between those children who had testing at one time point versus those who were seen for both one month and one year visits. 
Briefly, the FEBSTAT study prospectively recruited 199 children with FSE from June 2003 through March 2010 from five academic medical centers across the United States. Eligible subjects were children age 1 month to 5 years who presented with a first episode of FSE. FSE was defined as a FS [3, 19] lasting 30 minutes or longer, or repetitive FSs lasting at least 30 minutes without regaining alertness [20]. Children with prior afebrile seizures, acute CNS infection/insult and/or known severe neurologic disability were excluded. The detailed methodology of assembling the cohort is described in elsewhere [17, 18]. The Columbia Study of Febrile Seizures [21] recruited 159 children with a first febrile seizure who received almost the same work-up as the FEBSTAT cohort at baseline and at one-year. The seizure semiology and classification were all reviewed by the FEBSTAT phenomenology core and classified [18, 21]. The majority of the Columbia cohort $(90.6 \%)$ did not meet criteria for FSE but rather presented with a first simple FS (SFS) (64.2\%) or a first complex FS that was not FSE (26.4\%). The children with first SFS from the Columbia cohort have been used as controls for the FEBSTAT study for phenomenology and imaging $[8,18]$ and are the controls in this analysis.

There was no significant difference in age or gender between the FSE and SFS groups, but the SFS group was significantly more Hispanic (89\%) than the FSE population $(29 \%$; $p<0.001)$.

\section{Procedures}


Once identified, the children and their parents were recruited within 72 hours. Written informed consent was obtained from the parents in all cases. Clinical data was collected and the child received a neurological evaluation, EEG, MRI, and blood work (including serum to assay HHV6/HHV7 centrally for viremia or reactivation). One month later, the child was scheduled for a neuropsychological assessment and was once again evaluated by a neurologist. At that time additional blood work, and parental behavioral rating scales were completed. Neuropsychological assessment, EEG, MRI, neurological evaluation, blood work and behavioral rating scales were repeated one year after initial evaluation. The children in the Columbia cohort also received imaging at baseline and one year using a similar imaging protocol as well as cognitive testing at baseline and one year but did not have EEGs or virology testing $[18,21]$.

All procedures were approved by institutional review boards for the protection of human subjects at all the participating institutions.

\section{Measures}

Given the young age of the children at their one month visit (median age 17 months) and one year visit (median age 29 months), the test battery was designed to assess general development and aspects of verbal and non-verbal memory to the extent possible in this age group. Children who were over the age 5 at their one year visit were assessed with more comprehensive batteries including formal estimates of IQ, memory, and attention/concentration. The following measures were included in this analysis: 
- Bayley Scales of Infant Development- ${ }^{\text {nd }}$ Edition (Bayley-II) [22]

The Bayley-II assesses mental and motor development in infants and young children, aged 1 month to 36 months. Individually administered age appropriate items assess sensory acuity and response, early memory and problem solving, beginning language skills, basic abstract thinking and concept formation; as well as gross and fine motor skills to create composite scores. The Bayley-II is organized into two indices: mental development index (Bayley MDI) and psychomotor development index (Bayley PDI) which have a mean of 100 and a standard deviation of 15 [22]. When appropriate the Bayley-II index scores were corrected for prematurity. Children with FSE and controls with simple febrile seizures received these tests.

- Peabody Picture Vocabulary Test-3 ${ }^{\text {rd }}$ Edition (PPVT-3) [23] The PPVT-3 is a well-established measure of receptive vocabulary for children and adults aged 30 months and up. It shows excellent internal consistency and test-retest reliability, and its validity is supported by strong correlations with other measures of language [23, 24]. The PPVT has a mean of 100 and a standard deviation of 15 . Children with FSE and controls with simple febrile seizures received this test.

- McCarthy Scales of Children's Abilities- Memory Index [25] 
Children aged 30 months to 8 years received the McCarthy - Memory Index (MI) at baseline. At the inception of this study, the McCarthy was the only standardized measure that included an assessment of broad memory functioning, including visual, auditory, verbal and numerical memory, within this age range [25-27]. The Memory Index has a mean of 50 and a standard deviation of 10. Only children with FSE from the FEBSTAT cohort age 30 months or older received the McCarthy Scales.

Neuropsychological assessments were completed at each site by a licensed neuropsychologist or a trained psychometrician/ psychology technician under the supervision of a licensed psychologist. The test administration order was the same at each site. All paper tests were initially scored at the individual sites, and then sent to a central location for double scoring. Double scoring was performed by the first author (EFW) and trained psychology technicians under the supervision of a licensed clinical neuropsychologist (DM). Any methodological or scoring issues arising at each site were resolved at the central location. Results in this paper use the central scoring.

\section{Statistical analysis}

Frequencies, percentages, means, and standard deviations were used to summarize demographic characteristics, and seizure phenomenology. Chisquare tests were used for categorical variables and T-tests or ANOVA were used for continuous variables when scores on the Bayley mental, Bayley motor and Peabody Picture Vocabulary Test were compared by gender and 
race/ethnicity in children with FSE. T-tests were used to compare children with FSE to SFS controls on the Bayley and PPVT at one month and at one year in all ages and with restriction to those children aged 12 months or less. Linear regression compared FSE to simple febrile seizure controls on the Bayley and the PPVT with adjustment for maternal education.

All analyses were conducted via SAS 9.4

\section{RESULTS}

One hundred eighty two children with FSE completed the neuropsychological evaluation at one month and 151 children completed the neuropsychological evaluation at one year.

\section{Cognitive and motor development and memory in FSE}

At one month, mental and motor development index scores of children with FSE were within the low end of the average range, without significant differences between mental and motor development (Table 2). Duration of FSE, focality, prior febrile seizure, type of seizure (continuous versus intermittent), hippocampal volume, hippocampal malrotation (HIMAL), acute T2 signal in the hippocampus on MRI, and human herpes virus 6/ human herpes virus 7 infection (HHV6/7) did not predict Bayley scores at one month after FSE. Compared to Caucasian children, race/ethnicity was significant for African-American children on the MDI and for Hispanic children on the PDI. As would be expected, 10 children who were noted to have abnormal development (as assessed by medical report and neurological evaluation) at enrollment performed worse than 
the remaining 141 children on the Bayley MDI [Mean (SD) 67.4 (18.6) versus $93.7(14.1), p<0.0001]$.

Twenty-four children with FSE were old enough to complete the McCarthy and PPVT-3 at their one month visit. Overall performances were within the borderline to low average range $\left(6^{\text {th }}\right.$ to $14^{\text {th }}$ percentile when compared to their age peers) with significant differences between race/ethnicity groups. Compared to nonHispanic Caucasian children, African-American and Hispanic children performed significantly worse on the PPVT-3 ( $p=0.02$ and 0.049 , respectively). There were no significant differences in performances based on FS phenomenology or MRI findings.

At one year, Bayley-II, McCarthy Memory Index and PPVT-3 performances were all on the cusp of the low average to average range (Table 2). There were no significant differences due to gender, FSE duration, prior FS, or FS type. HHV6/7 infection appeared to be protective for memory scores on the McCarthy, and children who had acute T2 hippocampal findings on MRI demonstrated weaker receptive language abilities (Table 2). Hispanic children performed worse on the MDI than non-Hispanic children. Non-white children continued to perform worse on the PPVT-3, but the differences were no longer statistically significant $(p=0.075)$.

\section{Cognitive and motor development in FSE compared to simple febrile seizure controls}

When FSE was compared to SFS in children of all ages, there was no difference at one month for the Bayley MDI, Bayley PDI and PPVT-3. Children with FSE, 
however, performed about 5 standard points worse on Bayley PDI $(p=0.04)$ and about 8 standard points worse on the PPVT-3 $(p=0.03)$ when compared to the SFS cohort at one year. There was no difference in Bayley MDI. In a linear regression adjusted for maternal education, there was a 5-point increase in MDI for FSE ( $p=0.03$ ) at baseline, but no statistically significant findings for the PDI and PPVT-3 at baseline and one year. There were no differences between FSE and simple febrile seizures when children 12 months or younger were examined with separate exclusions for abnormal development and abnormal MRI. There was also no age effect within our cohort, meaning that children who were younger than one year at time of FSE were not different than those who were older than one year at time of FSE when compared with SFS controls.

\section{DISCUSSION}

This evaluation of children at one month and one year following first FSE demonstrated generally low average to average performance on measures of development, early memory, and receptive language ability. There were no significant differences based on gender, MRI, EEG, or phenomenology at baseline or one year but being white versus non-white was related to early developmental attainment and early language abilities. At one year, FSE was associated with weaker performance on a task of receptive language and mildly weaker psychomotor performance on the Bayley2. Acute hippocampal T2 findings on MRI correlated with weaker word recognition while HHV6/7 infection was associated with improved memory performances on the McCarthy. 
Overall, while the current performances of our cohort are slightly below normative expectations, these data are consistent with the results of large epidemiological studies evaluating cognition in children with FS and for FSE, which have for the most part established generally intact cognitive functioning following FS [12-14, $28,29,30]$ and good prognosis following FSE [31].

Although we demonstrate statistically weaker motor development in FSE than SFS at one year consistent with Dr. Hesdorffer's findings that children who had longer seizures tend to demonstrate motor delays [32], it should be noted that the difference in scores in not clinically significant- ie both cohorts of children perform on the cusp of the low average to average range. The weaker receptive performances on the PPVT in children with FSE compared to SFS does demonstrate an interesting trend toward possible temporal lobe involvement, but given the limited sample size in the SFS cohort we are hesitant to make further claims. Cognitively, the PPVT requires the child to bridge orally produced words with mental representations of those words activating the brains' processing of auditory information/language and recall.

Consistent with our one year data, Roy and colleagues reported that while children with FSE performed within the average range, their performances were below the control group and SFS peers [33]. Furthermore, they found that younger children ( $<11$ months) with FSE were more likely to evidence motor delay than older children [33]. Although we also found a difference in motor development at one year between children with FSE and SFS, when we looked at children primarily under 12 months of age at study enrollment, the difference 
disappeared. Verity and colleagues reported that a greater proportion of children who had FS prior to 12 months were more likely to be considered for special education in early childhood, but when reassessed at 10 years of age, those children performed as well as those who had FS when older than 1 year of age [1]. Within our cohort, children with FSE who were less than 12 month old at the baseline visit did not differ from the rest of the cohort.

The North London study also reported poorer performances in children with FSE compared to controls [34]. Their findings on the Bayley-III revealed cognitive index scores of 90-95 (average) at baseline and 92-93 (average) at one year, were is consistent with our cohort's performances on the Bayley-II [34]. Interestingly, we found that those children who had human herpes virus infection (HHV6/7) -performed half a standard deviation better on McCarthy memory task at one year after FSE than those who had FSE without HHV6/7 infection. This is consistent with our finding that when adjusting for age, HHV6/7 infection was associated with better growth of the right and left hippocampus [8]. Our sample size of children old enough to perform the McCarthy at one year post FSE is small due to the young median age of 17 months at FSE making it difficult to expand upon these findings. However, children with HHV6/7 infections and FSE performed similarly to those without HHV6/7 infection on the Bayley and PPVT. Therefore, although HHV6 and HHV7 infections has been linked to encephalitis and subsequent cognitive decline, evaluations of individuals who do not have encephalitis but present with FSE do not show higher levels of cognitive 
impairment in those where the FSE is associated with HHV6 or HHV7 infection [35].

The small sample size of older children at one year post FSE also limits our ability to extrapolate the cognitive correlates of MRI findings of $\mathrm{T} 2$ hyperintensities in the hippocampus. Children who had acute hippocampal T2 hyperintensity performed worse on the receptive vocabulary task (PPVT) than those who did not have those imaging markers. A recent study from Brazil demonstrated impaired PPVT performances in children with TLE and rolandic epilepsy [36]. Logically, children with acute hippocampal findings should have also demonstrated weaker performance on memory tasks, but most of these children were unable to complete the McCarthy memory scales. The five year post FSE testing is in progress and should provide an answer to this key question in the future.

Our findings demonstrated significantly weaker performance on receptive language (PPVT-3) measures in non-white children when compared with nonHispanic Caucasian children. We believe that this effect is moderated by the location of our medical centers in inner city areas where portions of the population have low SES and do not have access to early childhood education or children's books. The concept of the "black-white score gap" and its environmental associations is well known in the literature $[37,38]$. There has been evidence of 18-21 point differential between black and white children on the PPVT-R at age 3 , that is moderated by family income, structure and home environment [39], as well as, disproportianate bias towards minorities on the 
PPVT-3 [40] which would be complicated in households were English is not the primary language [41]. Similar concerns of normative bias against low- income children have also been raised with regard to the Bayley-II [42].

Memory performances on the McCarthy Scales Memory Index were within the borderline to average range $\left(12^{\text {th }}-27^{\text {th }}\right.$ percentile). While limited by the small sample size, this does appear to indicate that memory performances may be mildly reduced even early after FSE, raising the possibility of hippocampal involvement. Unfortunately, the Columbia SFS and FSE subjects did not complete these memory tasks and normal controls were unavailable. Additional limitations include the fact that the SFS Columbia cohort was demographically different (89\% Hispanic) than the FSE cohort (29\% Hispanic) and that this may have impacted upon our between group comparisons particularly on the mental and language tasks. Finally, we have a limitation shared across all cognitive research in young children secondary to the limited number of cognitive measures available for this age group. Although the field is slowly growing, there are relatively few aspects of cognitive performance that can be accurately assessed in an 18-month old child. As these children age, we will be able to investigate specific cognitive abilities with greater reliability. In summary we found generally low average to average abilities in children one month and one year following FSE with a trend towards slightly delayed motor and receptive language development at one year following FSE. Further followup of the FEBSTAT cohort will expand on these findings and provide much 
needed additional information on the cognitive functioning of children with FSE as they age.

\section{ACKNOWLEDGMENTS}

Supported by NINDS grant 2R37 NS43209 (PI: S. Shinnar, MD, PhD), NICHD grant 36867 (PI: D.C. Hesdorffer PhD) and Center for Clinical and Translational Research grant UL1TR000058. 
FEBSTAT Study Team:

Montefiore and Jacobi Medical Centers, Bronx, NY: Shlomo Shinnar MD

PhD (Pl), Jacqueline Bello MD, William Gomes MD PhD, James Hannigan RT,

Sharyn Katz R-EEGT FASET, David Masur PhD, Solomon L. Moshé MD, Ruth

C. Shinnar RN MSN, Erica F. Weiss PhD.

Ann \& Robert Lurie Children's Hospital, Chicago, IL: Leon G Epstein MD (site PI), John Curran MD, , Andrew Kim MD, Diana Miazga, Julie Rinaldi PhD.

Columbia University, New York, NY: Dale C. Hesdorffer PhD (site PI),

Stephen Chan MD, Veronica J. Hinton PhD, Binyi Liu MS, Yokasta Tineo BA.

Duke University Medical Center, Durham, NC: Darrell Lewis MD (site Pl),

Melanie Bonner PhD, Karen Cornett BS, MT, William Gallentine DO, James

MacFall PhD, James Provenzale MD, Allen Song $\mathrm{PhD}$, James Voyvodic $\mathrm{PhD}$,

$\underline{\text { Yuan Xu BS }}$

Eastern Virginia Medical School, Norfolk, VA: L. Matthew Frank MD (site PI), Joanne Andy RT, Terrie Conklin RN, Susan Grasso MD, Connie S. Powers REEGT, David Kushner MD, Susan Landers RT, Virginia Van de Water PhD. International Epilepsy Consortium/ Department of Biostatistics, Virginia Commonwealth University, Richmond Virginia: Shumei Sun $\mathrm{PhD}$ (site $\mathrm{PI}$ ), John M Pellock MD, Brian J Bush MSMIT, Lori L Davis BA, Xiaoyan Deng MS, Christiane Rogers, Cynthia Shier Sabo MS

Mount Sinai Medical Center, New York NY: Emilia Bagiella PhD 
Virginia Commonwealth University, Richmond, VA: John M Pellock MD (site PI), Tanya Brazemore R-EEGT, James Culbert PhD, Kathryn O'Hara RN, Syndi Seinfeld DO, Jean Snow RT-R

Additional Collaborators: Joan Conry MD Childrens National Medical Center, Safety Monitor; Tracy Glauser MD Cincinnati Childrens Medical Center, Genomics; Jeffrey L Noebels MD PhD, Baylor College of Medicine, Genetics;

Douglas R Nordli, MD, Children's Hospital of Los Angeles 
References

[1] Verity C, Butler N, Golding J. Febrile convulsions in a national cohort followed up from birth. I--Prevalence and recurrence in the first five years of life. BMJ 1985;290: 1307-1310.

[2] Stafstrom C. The incidence and prevalence of febrile seizures. In: Baram T, Shinnar S, editors. Febrile seizures. San Diego: Academic Press; 2002, p. 125.

[3] National Institutes of Health. Febrile Seizures: Consensus Development Conference Summary. Bathesda, MD: National Institute of Health; 1980.

[4] Steering Committee on Quality Improvement Management- Subcommittee on Febrile Seizures. Febrile Seizures: Clinical Practice Guideline for the Longterm Management of the Child With Simple Febrile Seizures. 2008;121: 12811286.

[5] Shinnar S. Febrile seizures. In: Swaiman K, Ashwal S, Ferriero D, Schor N, editors. Swaiman's Pediatric Neurology. Fifth ed: Elsevier Saunders; 2012, p. 790-797.

[6] Shinnar S. Febrile seizures and mesial temporal sclerosis. Epilepsy Currents 2003;3: 115-118. 
[7] Shinnar S, Bello JA, Chan S, Hesdorffer DC, Lewis DV, MacFall J, et al. MRI abnormalities following febrile status epilepticus in children The FEBSTAT study. Neurology 2012;79: 871-877.

[8] Lewis DV, Shinnar S, Hesdorffer DC, Bagiella E, Bello JA, Chan S, et al. Hippocampal sclerosis after febrile status epilepticus: The FEBSTAT study. Annals of Neurology 2014;75: 178-185.

[9] Provenzale JM, Barboriak DP, VanLandingham K, MacFall J, Delong D, Lewis DV. Hippocampal MRI signal hyperintensity after febrile status epilepticus is predictive of subsequent mesial temporal sclerosis. American Journal of Roentgenology 2008;190: 976-983.

[10] French J, Williamson P, Thadani V, Darcey T, Mattson R, Spencer S, et al. Characteristics of medial temporal lobe epilepsy: I. Results of history and physical examination. Annals of neurology 1993;34: 774-780.

[11] Mathern GW, Pretorius JK, Babb TL. Influence of the type of initial precipitating injury and at what age it occurs on course and outcome in patients with temporal lobe seizures. Journal of neurosurgery 1995;82: 220-227.

[12] Ellenberg JH, Nelson KB. Febrile seizures and later intellectual performance. Archives of neurology 1978;35: 17-21. 
[13] Verity CM, Greenwood R, Golding J. Long-term intellectual and behavioral outcomes of children with febrile convulsions. New England Journal of Medicine 1998;338: 1723-1728.

[14] Hirtz DG. Cognitive outcome of febrile seizures. In: Baram T, Shinnar S, editors. Febrile seizures. San Diego: Academic Press; 2002, p. 53-62.

[15] Bell BD, Giovagnoli AR. Recent innovative studies of memory in temporal lobe epilepsy. Neuropsychology review 2007;17: 455-476.

[16] Hermann B, Seidenberg M, Bell B, Rutecki P, Sheth R, Ruggles K, et al. The Neurodevelopmental Impact of Childhood-onset Temporal Lobe Epilepsy on Brain Structure and Function. Epilepsia 2002;43: 1062-1071.

[17] Shinnar S, Hesdorffer D, Nordli D, Pellock J, O'Dell C, Lewis D, et al. Phenomenology of prolonged febrile seizures Results of the FEBSTAT study. Neurology 2008;71: 170-176.

[18] Hesdorffer DC, Shinnar S, Lewis DV, Moshé SL, Nordli DR, Pellock JM, et al. Design and phenomenology of the FEBSTAT study. Epilepsia 2012;53: 14711480. 
[19] Sidenvall R, Forsgren L, Blomquist HK, Heijbel J. A community-based prospective incidence study of epileptic seizures in children. Acta Paediatrica 1993;82: 60-65.

[20] Maytal J, Shinnar S. Febrile Status Epilepticus. Pediatrics 1990;86: 611.

[21] Hesdorffer DC, Benn EKT, Bagiella E, Nordli D, Pellock J, Hinton V, Shinnar S for the FEBSTAT Study Team. Distribution of febrile seizure duration and associations with development. Ann Neurol 2011;70:93-100.

[22] Bayley N. Bayley scales of infant development: Manual: Psychological Corporation; 1993.

[23] Dunn LM, Dunn LM. Peabody Picture Vocabulary Test. 3rd ed. Circle Pines, MN: American Guidance Service; 1997.

[24] Strauss E, Sherman EM, Spreen O. A compendium of neuropsychological tests: Administration, norms, and commentary: Oxford University Press; 2006.

[25] McCarthy D. McCarthy Scales of Children's Abilities. In. San Antonio, Tx: Psychological Corporation; 1972.

[26] Forns-Santacana M, Göamez-Benito J. Factor structure of the McCarthy scales. Psychology in the Schools 1990;27: 111-115. 
[27] Mitchell WG, Chavez JM, Lee H, Guzman BL. Academic

underachievement in children with epilepsy. Journal of Child Neurology 1991;6: $65-72$.

[28] Knudsen FU. Febrile seizures: treatment and prognosis. Epilepsia 2000;41: 2-9.

[29] Chang YC, Guo NW, Huang CC, Wang ST, Tsai JJ. Neurocognitive Attention and Behavior Outcome of School-Age Children with a History of Febrile Convulsions: A Population Study. Epilepsia 2000;41: 412-420.

[30] Leaffer EB, Hinton VJ, Hesdorffer DC. Longitudinal assessment of skill development in children with first febrile seizure. Epilepsy \& Behavior 2013;28: 83-87.

[31] Neville BG, Chin RFM, Scott RC. Childhood convulsive status epilepticus: epidemiology, management and outcome. Acta Neurologica Scandinavica 2007;115: 21-24.

[32] Hesdorffer DC, Benn EKT, Bagiella E, et al. Distribution Of Febrile Seizure Duration And Associations With Development. Annals of neurology. 2011;70(1):93-100. doi:10.1002/ana.22368. 
[33] Roy H, Lippé S, Lussier F, Sauerwein HC, Lortie A, Lacroix J, et al.

Developmental outcome after a single episode of status epilepticus. Epilepsy \& Behavior 2011;21: 430-436.

[34] Martinos MM, Yoong M, Patil S, Chong WK, Mardari R, Chin RFM, et al. Early developmental outcomes in children following convulsive status epilepticus: A longitudinal study. Epilepsia 2013;54: 1012-1019.

[35] Zerr D, Komaroff A. Cognitive Dysfunction from HHV-6A and HHV-6B. In: Flamand L, Lautenschlager I, Krueger G, Ablashi D, editors. Human Herpesviruses HHV-6A, HHV-6B \& HHV-7: Diagnosis and Clinical Management: Elsevier Science; 2014.

[36] Boscariol M, Casali RL, Amaral MIR, Lunardi LL, Matas CG, CollelaSantos MF, et al. Language and central temporal auditory processing in childhood epilepsies. Epilepsy \& Behavior 2015;53: 180-183.

[37] Jencks C. Racial Bias in Testing. In: Jencks C, Phillips M, editors. The Black-White test score gap: Brookings Institution Press; 2011, p. 55-84.

[38] Sohn K. The dynamics of the evolution of the Black-White test score gap. Education Economics 2012;20: 175-188. 
[39] Brooks-Gunn J, Klebanov PK, Smith J, Duncan GJ, Lee K. The BlackWhite Test Score Gap in Young Children:Contributions of Test and Family Characteristics. Applied Developmental Science 2003;7: 239-252.

[40] Champion TB, Hyter YD, McCabe A, Bland-Stewart LM. "A Matter of Vocabulary": Performances of Low-Income African American Head Start Children on the Peabody Picture Vocabulary Test-III. Communication Disorders Quarterly 2003;24: 121-127.

[41] Laosa LM. Ethnic, socioeconomic, and home language influences upon early performance on measures of abilities. ETS Research Report Series 1984;1984: i-79.

[42] Black MM, Hess CR, Berenson-Howard J. Toddlers from low-income families have below normal mental, motor, and behavior scores on the revised Bayley scales. Journal of Applied Developmental Psychology 2000;21: 655-666. 
Table 1. Description of the FSE cohort at baseline

\begin{tabular}{|c|c|c|}
\hline & $\begin{array}{l}\text { FSE cases } \\
(\mathrm{N}=214)\end{array}$ & $\begin{array}{c}\text { Simple FS controls } \\
(N=102)\end{array}$ \\
\hline Mean age (months) (SD) & $20.2 \pm 12.7$ & $22.0 \pm 10.6$ \\
\hline Median age (months) (IQR) & $15.8(12.0-23.2)$ & 19.7(15.8 -- 25.03) \\
\hline \multicolumn{3}{|l|}{$\operatorname{Sex}(\%)$} \\
\hline Male & $111(51.9)$ & $59(57.84)$ \\
\hline Female & $103(48.1)$ & $43(42.16)$ \\
\hline $\begin{array}{l}\text { Mean duration of febrile } \\
\text { seizure (min) }\end{array}$ & $87.7(70.1)$ & $22.0 \pm 10.6$ \\
\hline $\begin{array}{l}\text { Median duration of febrile } \\
\text { seizure (IQR) (min) }\end{array}$ & $\begin{array}{c}70.0 \\
(45.0-105.0)\end{array}$ & $\begin{array}{c}3.00 \\
(2.00-5.00)\end{array}$ \\
\hline \multicolumn{3}{|l|}{ Type of seizure (\%) } \\
\hline Continuous & $121(56.5)$ & $102(100.00)$ \\
\hline $\begin{array}{l}\text { Intermittent without full } \\
\text { recovery }\end{array}$ & $69(32.2)$ & $0(0.00)$ \\
\hline $\begin{array}{l}\text { Intermittent with drug } \\
\text { therapy }\end{array}$ & $24(11.2)$ & $0(0.00)$ \\
\hline \multicolumn{3}{|l|}{ Focal seizure (\%) } \\
\hline Definitely & $148(69.2)$ & $0(0.00)$ \\
\hline No (Generalized) & $66(30.8)$ & $102(100.00)$ \\
\hline \multicolumn{3}{|l|}{$\begin{array}{l}\text { Definite cerebral } \\
\text { lateralization (\%) }\end{array}$} \\
\hline Left & $38(17.8)$ & $0(0.00)$ \\
\hline Right & $29(13.6)$ & $0(0.00)$ \\
\hline $\begin{array}{l}\text { No definite cerebral } \\
\text { lateralization }\end{array}$ & $147(68.7)$ & $102(100.00)$ \\
\hline \multicolumn{3}{|l|}{ Seizure classification (\%) } \\
\hline Generalized tonic-clonic & $66(30.8)$ & $102(100.00)$ \\
\hline Complex partial only & $4(1.9)$ & $0(0.00)$ \\
\hline $\begin{array}{l}\text { Partial with secondary } \\
\text { generalization }\end{array}$ & $144(67.3)$ & $0(0.00)$ \\
\hline \multicolumn{3}{|l|}{ Prior development (\%) } \\
\hline Normal & $183(85.5)$ & $100(98.04)$ \\
\hline Suspect & $13(6.1)$ & $2(1.96)$ \\
\hline Abnormal & $18(8.4)$ & $0(0.00)$ \\
\hline \multicolumn{3}{|l|}{ Baseline MRI findings (\%) } \\
\hline Any definite abnormality & $140(73.7)$ & 79 ( 89. 77) \\
\hline $\begin{array}{l}\text { Increased T2 signal in the } \\
\text { hippocampus }\end{array}$ & $50(26.3)$ & $9(10.23)$ \\
\hline \multicolumn{3}{|l|}{ HIMAL (\%) } \\
\hline No & $140(89.2)$ & $79(97.53)$ \\
\hline
\end{tabular}




\begin{tabular}{|lcc|} 
Yes & $17(10.8)$ & $2(2.47)$ \\
HHV6 and HHV7 (\%) & $111(65.7)$ & NA \\
Yes & $58(34.3)$ & NA \\
Acute T2 Signal & & \\
No & $140(88.6)$ & $102(100.00)$ \\
Yes & $18(11.4)$ & $0(0.00)$ \\
Baseline EEG findings (\%) & & \\
Any abnormality & $108(54.3)$ & NA \\
Epileptiform abnormality & $91(45.7)$ & NA \\
\hline
\end{tabular}

NA- Not applicable 
Table 2. Cognitive Performance at One Month and One Year in FSE by Demographic Factors

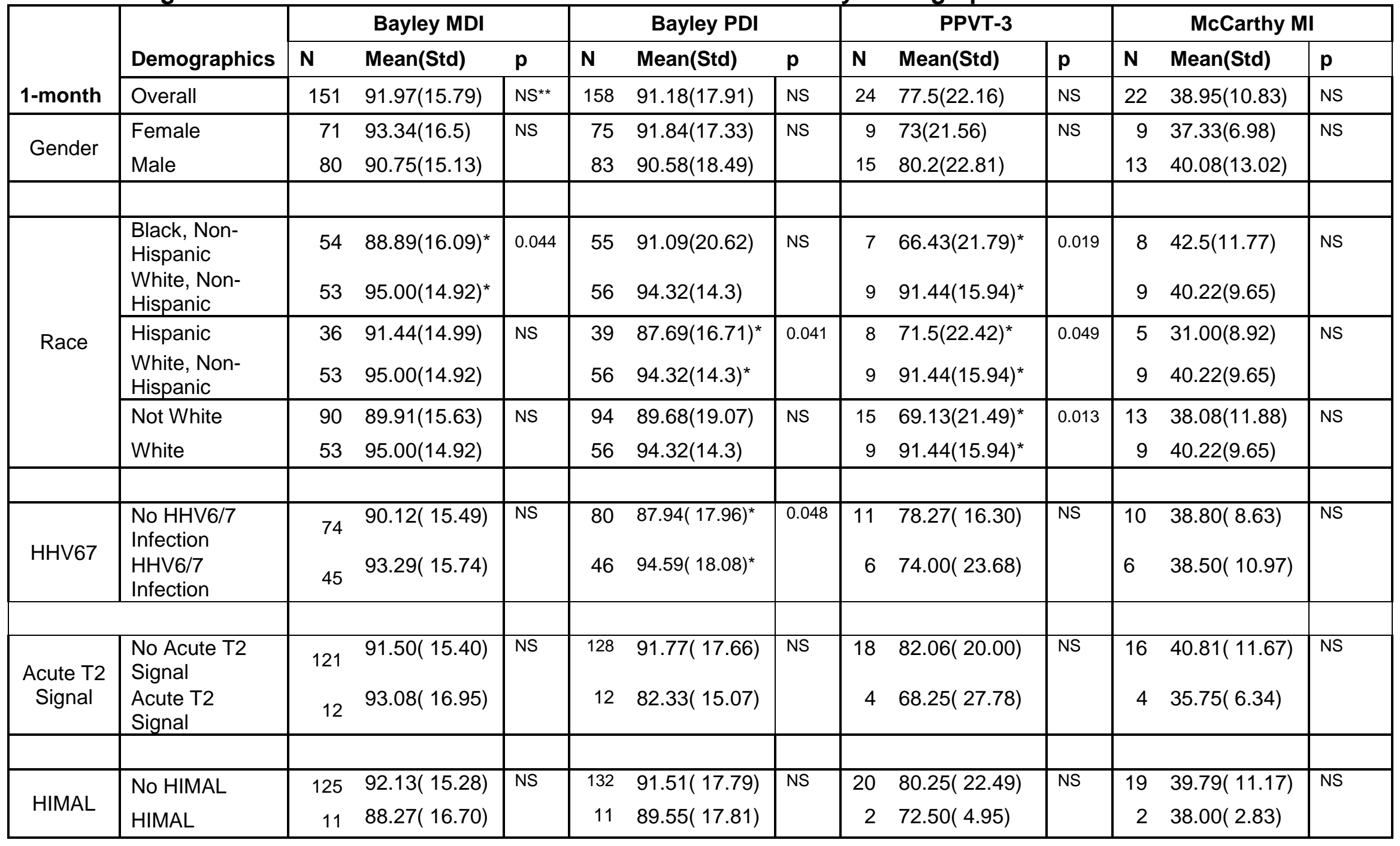




\begin{tabular}{|c|c|c|c|c|c|c|c|c|c|c|c|c|c|}
\hline 1-year & Overall & 95 & $87.40(19.38)$ & NS & 95 & 89.33(19.50) & NS & 56 & $85.54(21.45)$ & NS & 40 & $42.45(8.24)$ & NS \\
\hline Gender & $\begin{array}{l}\text { female } \\
\text { male }\end{array}$ & $\begin{array}{l}45 \\
50 \\
\end{array}$ & $\begin{array}{l}89.76(21.24) \\
85.28(17.48) \\
\end{array}$ & NS & $\begin{array}{l}44 \\
51\end{array}$ & $\begin{array}{l}90.77(19.88) \\
88.08(17.32) \\
\end{array}$ & NS & $\begin{array}{l}22 \\
34 \\
\end{array}$ & $\begin{array}{l}85.64(23.62) \\
85.47(20.30) \\
\end{array}$ & NS & $\begin{array}{l}16 \\
24 \\
\end{array}$ & $\begin{array}{l}42.38(6.93) \\
42.50(9.15) \\
\end{array}$ & NS \\
\hline \multirow{3}{*}{ Race } & $\begin{array}{l}\text { Black, Non- } \\
\text { Hispanic } \\
\text { White, Non- } \\
\text { Hispanic }\end{array}$ & $\begin{array}{l}29 \\
32\end{array}$ & $\begin{array}{l}86.59(17.17) \\
93.47(13.88)\end{array}$ & NS & $\begin{array}{l}27 \\
31\end{array}$ & $\begin{array}{l}93.11(17.73) \\
86.68(13.72)\end{array}$ & NS & $\begin{array}{l}18 \\
22\end{array}$ & $\begin{array}{l}79.11(19.43) \\
91.59(23.13)\end{array}$ & NS & $\begin{array}{l}12 \\
17\end{array}$ & $\begin{array}{l}43.42(8.53) \\
43.06(8.33)\end{array}$ & NS \\
\hline & $\begin{array}{l}\text { Hispanic } \\
\text { White, Non- } \\
\text { Hispanic } \\
\end{array}$ & $\begin{array}{l}30 \\
32\end{array}$ & $\begin{array}{l}81.00(23.71)^{*} \\
93.47(13.88)^{*}\end{array}$ & 0.016 & $\begin{array}{l}33 \\
31\end{array}$ & $\begin{array}{l}88.39(21.88) \\
86.68(13.72)\end{array}$ & NS & $\begin{array}{l}14 \\
22\end{array}$ & $\begin{array}{l}83.29(20.71) \\
91.59(23.13)\end{array}$ & NS & $\begin{array}{r}9 \\
17\end{array}$ & $\begin{array}{l}39.22(8.11) \\
43.06(8.33)\end{array}$ & NS \\
\hline & $\begin{array}{l}\text { Not White } \\
\text { White }\end{array}$ & $\begin{array}{l}59 \\
32\end{array}$ & $\begin{array}{l}83.75(20.77)^{*} \\
93.47(13.88)^{*}\end{array}$ & 0.009 & $\begin{array}{l}60 \\
31\end{array}$ & $\begin{array}{l}90.52(20.1) \\
86.68(13.72)\end{array}$ & NS & $\begin{array}{l}32 \\
22\end{array}$ & $\begin{array}{l}80.94(19.78) \\
91.59(23.13)\end{array}$ & NS & $\begin{array}{l}21 \\
17\end{array}$ & $\begin{array}{l}41.62(8.42) \\
43.06(8.33)\end{array}$ & NS \\
\hline HHV67 & $\begin{array}{l}\text { No HHV6/7 } \\
\text { Infection } \\
\text { HHV6/7 } \\
\text { Infection } \\
\end{array}$ & $\begin{array}{l}47 \\
26\end{array}$ & $\begin{array}{l}88.30(21.77) \\
86.42(16.12)\end{array}$ & NS & $\begin{array}{l}48 \\
25\end{array}$ & $\begin{array}{l}88.13(21.37) \\
92.44(14.03)\end{array}$ & NS & $\begin{array}{l}29 \\
19\end{array}$ & $\begin{array}{l}87.76(19.31) \\
81.32(23.92)\end{array}$ & NS & $\begin{array}{l}25 \\
10\end{array}$ & $\begin{array}{l}40.52(8.01)^{\star} \\
46.70(7.94)^{\star}\end{array}$ & 0.047 \\
\hline $\begin{array}{c}\text { Acute T2 } \\
\text { Signal }\end{array}$ & $\begin{array}{l}\text { No Acute T2 } \\
\text { Signal } \\
\text { Acute T2 } \\
\text { Signal } \\
\end{array}$ & $\begin{array}{r}77 \\
4\end{array}$ & $\begin{array}{l}88.52(19.15) \\
82.75(24.16)\end{array}$ & NS & $\begin{array}{r}77 \\
4\end{array}$ & $\begin{array}{l}89.97(18.97) \\
77.75(15.33)\end{array}$ & NS & $\begin{array}{r}47 \\
5\end{array}$ & $\begin{array}{l}89.87(15.39)^{\star} \\
68.00(30.19)^{*}\end{array}$ & 0.009 & $\begin{array}{r}36 \\
1\end{array}$ & $\begin{array}{l}42.31(8.12) \\
34.00(.)\end{array}$ & NS \\
\hline HIMAL & $\begin{array}{l}\text { No HIMAL } \\
\text { HIMAL }\end{array}$ & $\begin{array}{r}79 \\
4\end{array}$ & $\begin{array}{l}88.73(19.18) \\
76.00(21.53)\end{array}$ & NS & $\begin{array}{r}79 \\
4\end{array}$ & $\begin{array}{l}89.89(18.66) \\
77.50(20.87)\end{array}$ & NS & $\begin{array}{r}46 \\
8\end{array}$ & $\begin{array}{l}87.07(20.96) \\
85.13(20.29)\end{array}$ & NS & $\begin{array}{r}30 \\
9\end{array}$ & $\begin{array}{l}43.20(7.77) \\
40.44(10.13)\end{array}$ & NS \\
\hline
\end{tabular}

* T-Test Significance Level: <.05; MDI: Mental Development Index; PDI: Psychomotor Development Index; PPVT: Peabody Picture Vocabulary Test; MI: Memory Index

** NS: Not Significant 
Table 3. Comparison of Cognition Scores among FSE and SFS and in those 12 months or younger

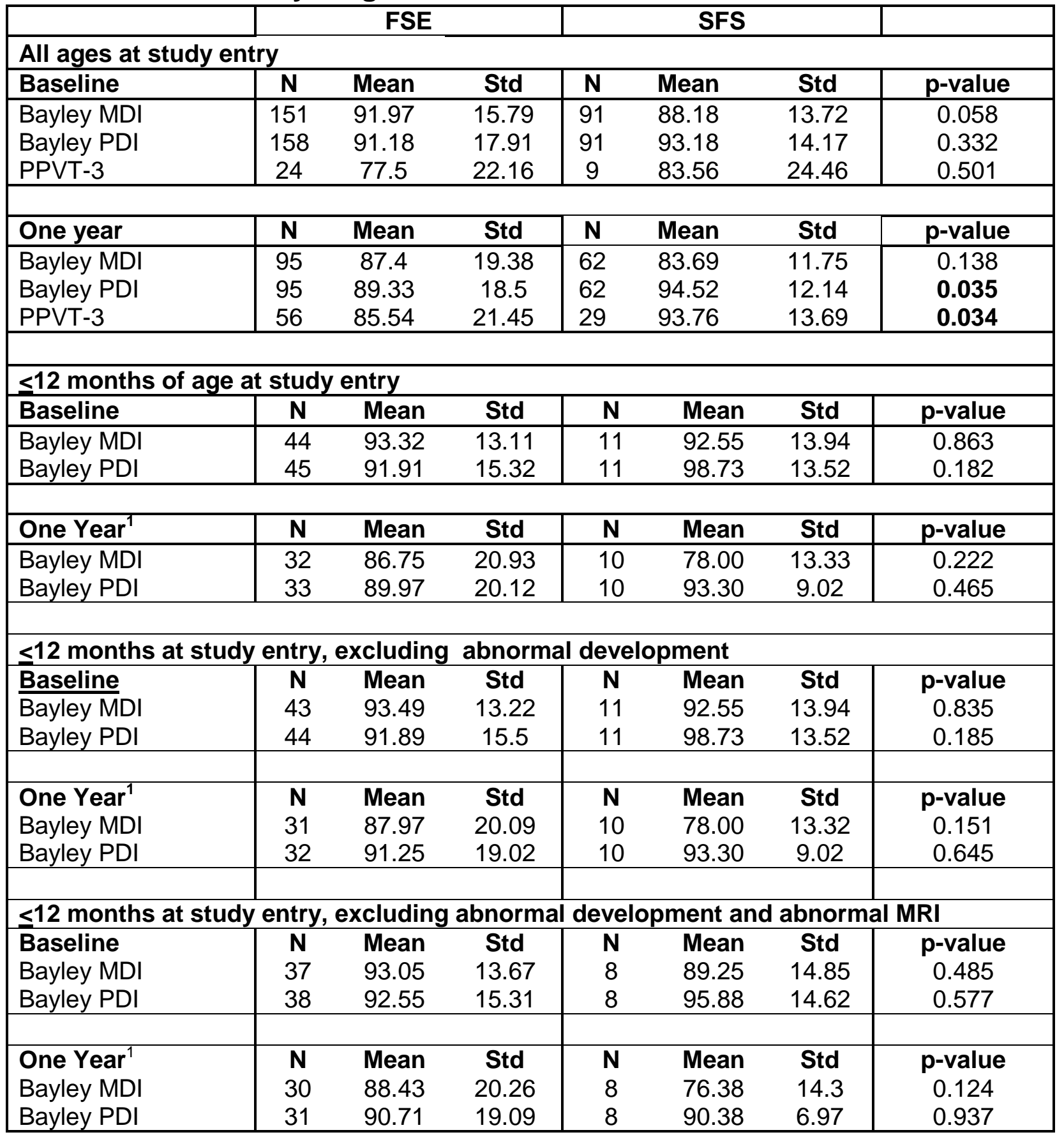

MDI: Mental Development Index; PDI: Psychomotor Development Index ; PPVT:

Peabody Picture Vocabulary Test; MI: Memory Index; ${ }^{1}$ only 2 with PPVT-3 in FSE and none in simple febrile seizure 